\title{
The Limitations of Front-End Loading in Undergraduate University Programs
}

\author{
Jeanne Maree Allen \\ Faculty of Education \\ University of Tasmania \\ Mark Sinclair \\ Faculty of Education \\ University of Technology Sydney
}

This paper shows how Mead's theory of emergence can prove explanatory in how the theory-practice gap is co-created and sustained in front-end loading university programs. Taking teacher education as an exemplar, we argue that the trainee teacher encounters different and oft-times conflicting environmental, social and cultural conditions in the two "fields of interaction" of the training program, namely, on-campus work and inschool experience. The argument draws on interview and focus group data collected via a study of first-year graduate teachers of an Australian teacher education program. We conclude that role taking and self-regulated behaviour within the two environmental fields of interaction in front-end loading programs inhibit the trainee professional from exercising the power of agency to implement theory learned at university in practice in the workplace. Further, we propose that Mead's theory of emergence proves effective in explaining a major limitation of front-end-loaded university programs.

\section{Introduction}

Earlier this decade, Chang (2004) advocated the use of Mead's theory of emergence as a framework for multilevel sociological inquiry. Chang and others (Blumer, 1969; Cook, 1993; El-Hani \& Pihlström, 2002) maintain that Mead's theory has been largely overlooked by scholars and remains only partially explored, due to the often fragmentary character of his writings and his failure to develop the theory systematically. However, as Chang (2004) points out, the outline of the theory can be found in Mead's work, particularly in Mind, Self and Society (1934) and The Philosophy of the Act (1938). In this paper, using Teacher Education as an exemplar, we use Mead's theory to provide insight into the theory-practice gap commonly associated with front-end loading in undergraduate university programs.

\section{Turning theory into practice}

Pfeffer and Sutton $(2000$, p. 4) refer to the nexus between theory and practice as the "knowing-doing problem," the problem lying in the fact that there is a disparity between the theory of the pre-service program or preparation and the practice in the workplace. The phenomenon is found across a broad range of disciplines, organisations and professions, and has been the focus of considerable research (Brouwer \& Korthagen, 2005; Reid \& O'Donoghue, 2001; Reidy, 2006; Yayli, 2008). 
For example, research in nurse education has addressed the theory-practice phenomenon in ways including workplace-integrated learning, how to facilitate learning in the clinical area, and the role of the nurse educator (Beattie, 2001; Landers, 2000; Spouse, 2001). Research in medical and engineering education has addressed similar issues, particularly regarding how to reconcile university-learned theory with workplace practice (Davison, 2005, Dec 12-15; Hudson, Buckley, \& McMillen, 2001). Further, as Brouwer and Korthagen $(2005$, p. 154) point out, "a gap between theory and practice seems to persist across different times and contexts." It would seem that the difficulty of integrating theory and practice in professional education has long generated much debate but resulted in few solutions (Korthagen \& Kessels, 1999) ${ }^{1}$. In this study, Mead's theory of emergence enables us to focus on the experiences of individuals caught "in the gap."

\section{Mead's theory of emergence}

The primary understanding involved in Mead's theory of emergence is that when a living form of some kind interacts with its environment, some new object is likely to emerge. This study sees the interaction of the individual and his/her front-end program as giving rise to a graduate professional. Specifically, the process of becoming a graduate involves one who has chosen to train for a profession (an individual) entering the undergraduate program (an environment) and interacting with this environment. During this interaction Mead argues that a process of emergence takes place such that there ensues from it a graduate (an emergent). This is consistent with his premise that "when things get together, there then arises something that was not there before" (Mead, 1938, p. 641) In other words, emergence gives rise to new objects and new situations (Maines, 2001). These fundamental concepts are captured by Chang's (2004) interpretation of Mead's model of emergence in human society, as shown in Figure 1. Chang's has been selected as the preferred model because he has taken up Mead's theory and applied it substantially (see, for example, Chang, 2000, 2005).

Figure 1: Mead's theory of emergence in human society (adapted from Chang, 2004)

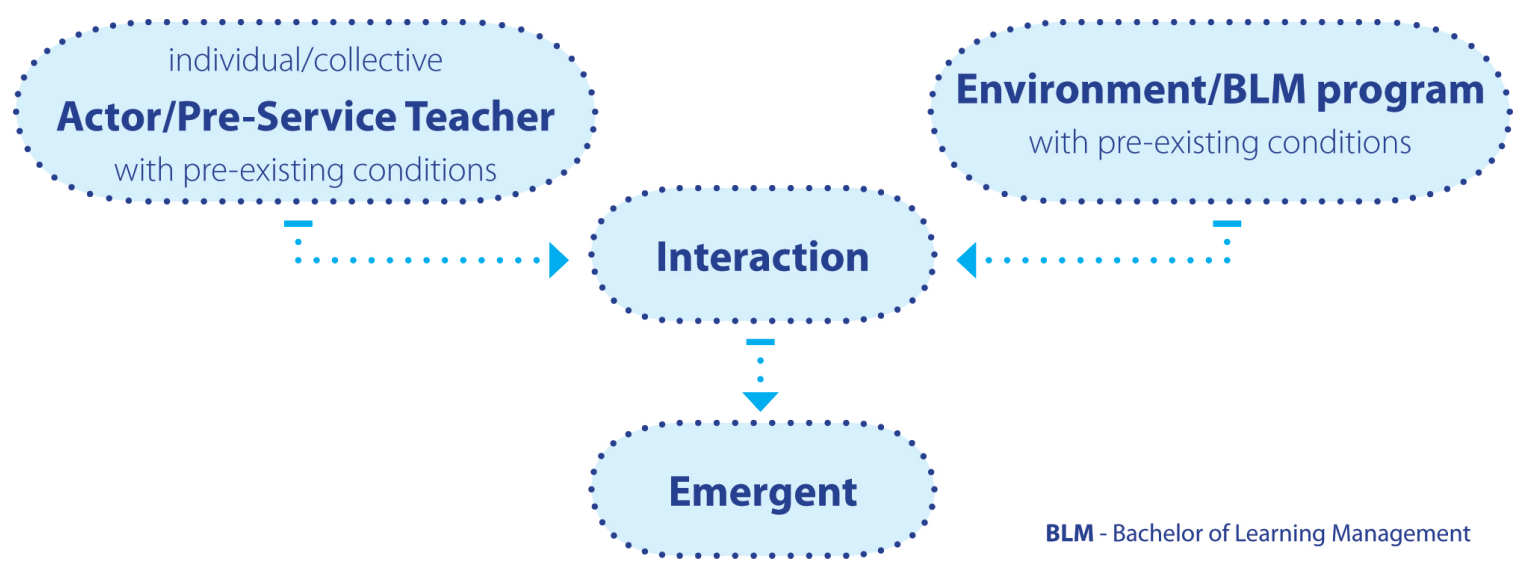

\footnotetext{
1 The relevance of coursework taught on campus and the value of university "theory" are also broadly contested. Discussion of these issues is beyond the scope of this paper.
} 
Pre-existing conditions associated with both the individual and the environment are axiomatic to emergence and underlie the realisation of the interaction (Mead, 1934). Changes to the pre-existing conditions of the individual and/or to the environment will create a different type of emergent (Mead, 1934). This premise is the first of two that determine the nature of the emergent. The second is that the nature of interaction taking place between the individual and the environment is of primary importance in creating the emergent (Reichers, 1987). For the purposes of this paper, we focus on the second of these two premises.

\section{Nature of the interaction}

The nature of the interaction that takes place between the student and his/her undergraduate program can be operationalised as follows. The traditional front-end program is conceived as a singular environment comprising two "fields of interaction" (FoI) (Mead, 1934, p. 249), the university (FoI-a) and the workplace (FoI-b). That is, students undertake on-campus studies and integrate the theory learned in this field with the practice of the workplace. Widely referred to as work integrated learning (Patrick, Peach, \& Pocknee, 2008) or work based learning (Boud, 2001), these types of programming arrangements are commonplace in front-end university programs (Patrick, et al., 2008). It is our proposition that undergraduate students frequently encounter contradictory expectations or "obdurate responses" (Blumer, 1969, p. 22) between the two fields of interaction and that this impedes their ability to integrate theory and practice. We now show how certain mechanisms condition individuals' actions during interaction.

\section{Mechanisms conditioning individuals' actions}

In Mead's view, a number of mechanisms condition human action. Two of particular relevance to this study are the individual's role taking and the individual's role takingbased self-regulation (henceforth, "self-regulation"). Following Mead (1934, p. 141), role taking is one of the "specifically social expressions of intelligence" that shape the interpersonal nature of the work of the professional. It involves the self engaging in a reflective dialogue with itself in order to act in role and is an inevitable consequence of human interaction; "there are all sorts of selves answering to all sorts of different social interactions" (Mead, 1934, p. 142). Role taking involves selecting from the number of alternatives present the ones believed to be most appropriate and then enacting them (Mead, 1934). The type and nature of role that the individual adopts are dependent on the vantage point from which the individual perceives the social and non-social environment, and the level at which the individual interacts.

Mead (1934, p. 173) views the self as divided into the " $P$ " and the "Me," with the $I$ representing the creative, spontaneous self and the $M e$ referring to the outward, socialised aspect of the self. The $M e$ is learned in interaction with others and with the environment. It includes both knowledge about that environment (including society) and a sense of who he or she is: a sense of self. The $I$ is the active aspect of the self, which acts creatively but within the context of the Me. Both parts of the self come together during the process of role taking. Mead (1934, p. 186) describes the relationship in these terms: 
The "I" is the response of the organism to the attitudes of the others; the "Me" is the organized set of attitudes of others which one himself [sic] assumes. The attitudes of the others constitute the organized "Me"; one who reacts towards that as an "I."

Reflective thinking shapes the actions of the self by enabling individuals to develop and sustain a role (Mead, 1934). Role taking is the means by which the self is able to structure and react to its own experiences, make reflexive adjustments and thus establish situational identity/ies (Mead, 1934; Reichers, 1987). It further involves individuals seeing themselves as others might see them and regulating their behaviour accordingly. This is what is meant by "self-regulation." Individuals undergoing the process of becoming professionals must experience the process of role taking in order to regulate their behaviour and develop a sense of professional identity (Mead, 1934). This involves them consciously and regularly evaluating and adjusting what they are doing when performing tasks and interacting with others.

As outlined above, front-end loading programs such as Teacher Education comprise two fields of interaction. Each consists of key learning experiences, conditions and requirements. Together these features of the environment wield an influence on the development of the student, but are also mediated by his/her stance. Indeed, the student's self-regulation is pivotal. Maines (2001, p. 47) is instructive on this issue:

The individual selects out from the world that which is situationally meaningful, or pragmatic, and adjusts to events that the world thrusts upon the individual. The adjustive responses transform the world in terms of its meaning, while simultaneously establishing the structures that condition the appearance of future events.

In the case of the student, this means that he/she selects feature/s that are meaningful to him/her and adjusts his/her behaviour accordingly. This selection, however, is constrained by the determining influence of the environment. As a member of the university program collective, each student teacher shares a commitment to certain understanding and commitments. For the student in a front-end program, how this commitment plays out in practice is a function of the strength of the pre-conditions discussed earlier, and, interactions between the on-campus program on the one hand and the workplace on the other. The relationship between these core concepts is shown in Figure 2 . 
Figure 2: Relationship between the core theoretical concepts in Teacher Education

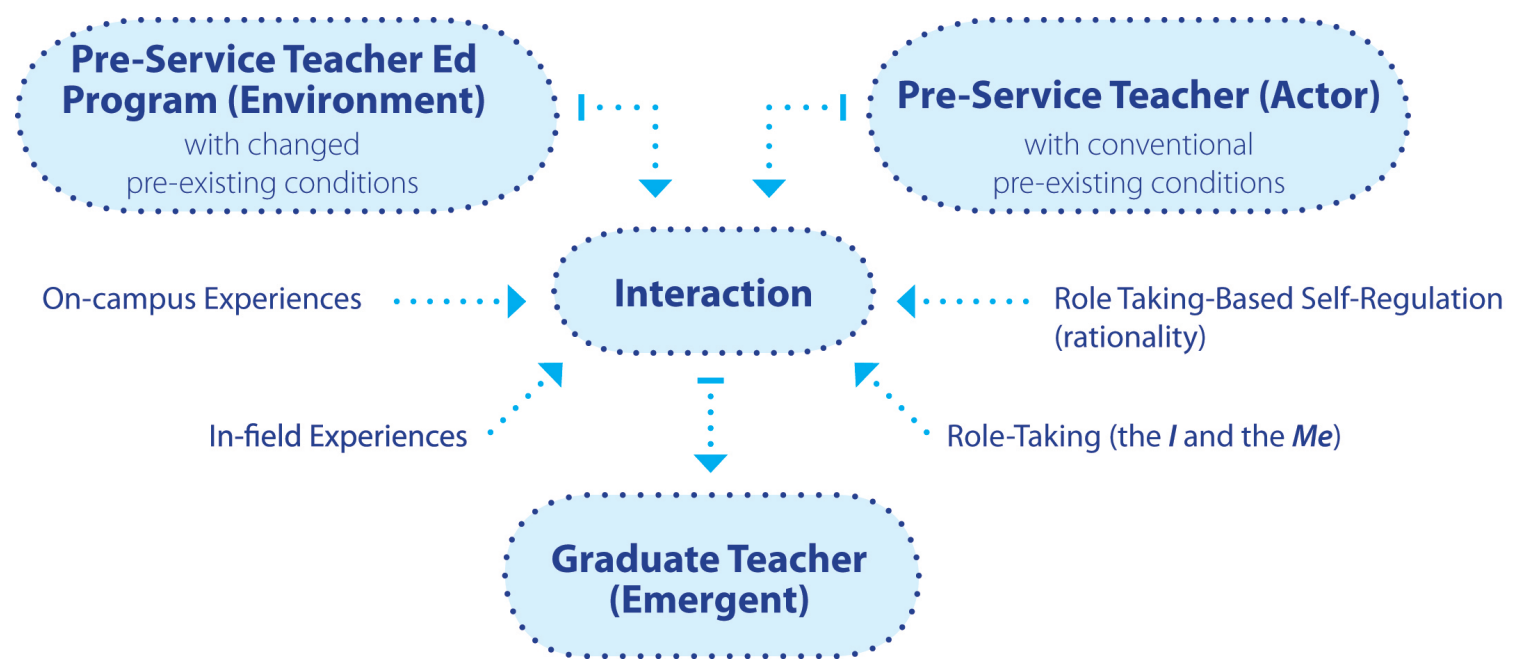

Before discussing these matters in light of our data, we provide the context for this work.

\section{The Bachelor of Learning Management}

The context of this study is teacher education based on a Bachelor of Learning Management (BLM) degree that is conceptually different to a conventional Bachelor of Education (BEd) degree. A core goal of the BLM is to eradicate the theory-practice gap that has been endemic in teacher preparation since its establishment as a profession in the 1960s (Lynch, 2003). During the program, students undertake thirty-two courses from four knowledge domains, namely, Essential Professional Knowledge, Futures, Networks and Partnerships, and Pedagogy. Courses within these domains, particularly a number of keystone courses, include a theoretical background in instructional theory and design, and an understanding of the meta-analysis of teaching/learning, with a particular focus on the role of the teacher in achieving learning outcomes in students (Allen \& Smith, 2007). Key Learning Area (KLA)- or discipline-based courses are also included in the program. In-field experiences in Teaching Schools are structured in such a way that students must demonstrate their understanding of and ability to apply knowledge learned on campus in the classroom. The program provides 111 days of in-field experience, comprising 100 days' experience in schools. Students spend progressively longer in schools each year. In their final year, they undertake a ten-week internship during which time they are granted provisional registration by the state statutory authority.

The nature of the interaction between the pre-service teacher and the teacher education program has altered since the introduction of the BLM. Course content is significantly different from the BEd program that was anchored in the discipline languages of educational psychology, sociology of education, school curricula and social contexts of schooling (Smith \& Moore, 2006). Course delivery has not changed markedly apart from a stronger emphasis on web-based instruction. The nature and length of in-field experiences represent a significant change as the practicum-type periods in schools common to the BEd model of teacher preparation have been reconceptualised in the BLM 
as portal tasks, periods when students put into practice the concepts and theories explored on campus (Smith \& Moore, 2006).

Portal tasks are situated throughout the program to target a range of standards against which students must demonstrate competence in order to proceed with their studies. They entail a structured and mentored period of theory application in real-life settings and aim to secure the theory/practice nexus considered vital in the preparation of educators (Smith \& Moore, 2006). Similar arrangements apply to the ten-week internship. A central tenet of the portal task arrangement is that all participants, students, academic staff and supervising teachers, follow "the same script" (Smith \& Moore, 2006, p. 21). This is achieved through partnership arrangements that include industry input into BLM course work and assessment and shared professional development (Allen \& Butler-Mader, 2007). The BLM student also spends $14 \%$ longer in schools than did his/her earlier BEd counterpart. In Median terms, the program's environment comprises the two "fields of interaction" (Mead, 1934, p. 249) of the university and Teaching Schools.

\section{Method}

Data in this study were collected from a sample of first-year graduates of the BLM, all teaching in primary schools in regional Australia. A purposive sampling strategy (Sarantakos, 2005) was used to select participants and, of sixteen participants identified, fourteen agreed to participate in the study. The number of participants enabled the study to sustain an in-depth focus on their experiences of interacting in the two environmental fields of interaction of the university and the Teaching School. Individual interviews and two focus group discussions were chosen as data gathering techniques in this study because they could help provide an authentic insight into the way the participants understand and engage with the world (Silverman, 2004). The interviews were semistructured to facilitate the free expression of the participants' thoughts. This type of interviewing involves emphasising participants' definitions of situations, encouraging them to structure accounts of situations and enabling them to introduce their notions of relevance (Cohen, Manion, \& Morrison, 2007). Focus groups allowed us to re-examine in a different context some of the responses that participants had given in the interviews. They also provided an opportunity to subject the individual accounts of participants to "probing and critical collective discussion" by a group of their peers (Blumer, 1969, p. $52)$.

Analysis of the data set was guided by procedures of coding, categorising and identifying themes as proposed by Coffey and Atkinson (1996) and Miles and Huberman (1994). Thus, the data were scanned for themes and relationships among these themes. Hypotheses were then developed and modified through hermeneutic cycles of close interpretative readings (Kelchtermans \& Vandenberghe, 1994) of participants' articulations about their experiences of turning theory into practice during their preparation (i.e. as student teachers). The same process was repeated across transcripts to identify commonalities across all the data. This resulted in the creation of ten categories which were then grouped into three themes: workplace readiness, futures orientation and capacity to implement BLM pedagogical design. For the purposes of this paper, we draw from our interpretation of the data across these themes those data which show how participants engaged with theory and practice in the two BLM fields of interaction. 


\section{Findings}

Four major findings emerged from the analysis of the data. First, participants differentiated between in-field experience as practical, real and immediate and oncampus work as theoretical and remote. Some demonstrably privileged the former over the latter and devalued and at times denigrated the theory they were taught, finding it to be of limited use as they progressively took on the role of the teacher. While the majority saw value in what they had learned on campus for the theoretical and practical insights that it offered, unless they witnessed or experienced it in application the value was not cached into becoming a "real teacher."

Second, during their pre-service preparation informants emulated the practice of their supervising teachers and other seasoned practitioners in the school environment and valued the practice of these individuals over their own. For many participants, this meant that they abandoned practice learned at university in favour of following and, at times, mimicking the teaching practice of their supervising teachers. In many cases, they also utilised planning materials and resources used by experienced and expert staff in preference to those they used in the BLM. Their use by experienced teachers seemed to imply they were valuable resources in the view of many informants.

Third, despite the articulated conceptual synergies between the university and school partners about what the work of student teachers in school should entail, many participants were unable or unprepared to implement key features of their on-campus learning during portal tasks and internship. Many had little choice but to conform to the status quo with supervising teachers unaware of or unconvinced by the types of strategies our informants were instructed to implement by their university teachers. Some examples of experienced teachers taking an active interest in some facets of the participants' knowledge and skills once they had become teachers was reported.

Fourth, only one participant believed herself to be workplace ready upon graduation. This can be attributed to two factors. First, the concept of workplace readiness in the BLM model implies a specific set of skills, knowledge and capabilities (Lynch \& Smith, 2006) but respondents in this study seemed to interpret the concept to mean ready to deal proficiently with any situation in the workplace and equated it with expertise generated through experience. Second, the majority of participants compared themselves unfavourably to seasoned and expert teachers, believing them to epitomise workplace readiness. Accordingly, they did not consider themselves to have the requisite skills to be workplace ready. Many questioned whether pre-service preparation could possibly enable novitiate teachers to be workplace ready.

\section{Discussion}

In the following discussion, we interpret the empirical findings of this study through the framework of Mead's theory of emergence ${ }^{2}$.

2 In doing so, we acknowledge that that there are plausible alternative explanations of students' claims which, for the purposes of this paper, we do not discuss. 


\section{Frames of reference}

It will be recalled that the environmental preconditions of the BLM involve two fields of interaction (FoI): the university (FoI-a) and the Teaching Schools (FoI-b). Teaching Schools set up student teachers and practising teachers ("experienced teachers" hereafter) to interact in order to devise teaching experiences for the classroom. They do this through interaction in the school. While this potentially brings together the pre-existing conditions of the two FoI, it also involves pre-existing conditions of the two Is: the experienced teacher and the student teacher. The following data samples provide evidence of how this interaction unfolds in practice:

I couldn't use BLM strategies because my teacher in two of the portal tasks hadn't even heard of half the stuff we'd been taught. (Inez) ${ }^{3}$

There's no way I would have gone in using the Eight Learning Management Questions ${ }^{4}$ and that stuff. No one knew anything about it. I talked a bit about stuff I'd learned [at uni] but there was always so much to do and we had to keep on track. (Desley)

In these examples, neither Inez nor Desley had substantive conversations about practices learned at university in the Teaching Schools field. Their transcripts further show that, while they both mentioned some BLM practices in their meeting with experienced teachers, neither pursued the issue of implementing them. They had encountered what Blumer (1969, p. 22) calls an "obdurate effect" in the environment; their understanding of pedagogical practice learned at university in FoI-a did not match the reality of others in the FoI-b, the Teaching School.

Also evident in Inez' and Desley's remarks is that experienced teachers did not engage them in further conversation on the topic. The responses of the Is in the school context were such that the desired pre-existing conditions of the university were difficult to achieve through interaction in the Teaching Schools. The student teachers' behaviour can be explained through the regulation of their $I$ by their $M e$ as they started to see themselves as they believed significant others (experienced teachers) saw them, adapting their behaviour accordingly. As aspirants to the group 'experienced teachers', Inez and Desley were seeking to adopt similar perspectives about what counted as pedagogical strategies in FoI-b. They regulated their interactional behaviour by following the practices they observed in order to become more like the other, to belong to the social group. It was their ability to define teaching situations from the same standpoint as experienced teachers that made their personal controls possible (Mead, 1934).

\footnotetext{
${ }^{3}$ Pseudonyms for participants are used throughout the paper.

${ }^{4}$ The Eight Learning Management Questions (Lynch \& Smith, 2006) are a set of sequential design based questions that form part of the BLM Learning Design. The expectation is that all BLM students master and implement the BLM Learning Design during their preparation and infield experience.
} 
In turn, the responses of experienced teachers to the students' talk about BLM pedagogical practices reflect their own pre-existing conditions and sense of self as teachers. The student explanations of BLM requirements did not fit experienced teachers' preconceptions of "teaching." By filtering out student ideas, experienced teachers' identities as professionals who know what needs to be known about teaching were protected. The imbalance in the power arrangements between the experienced teacher and the student teacher ensured that, in this relationship, the experienced teachers' views held sway and the pre-existing conditions of the university did not wield substantial power over the meaning-making of participants (Bullough \& Draper, 2004; Hargreaves, 2000).

The following comments additionally show how student teachers encountered a different frame of reference in FoI-b:

Being in the schools was like a different world. I didn't really think about uni. [One of my lecturers] visited during one of my portal tasks, I think it was the second one, but she didn't stay long. That was the only contact I ever had and the teachers had no idea of what I was doing at uni. I was really disappointed about that. (Fiona)

The supervising teachers I had said they had no idea about what we were doing at uni. None of them had had much contact at all with the uni, I don't think. I found it more practical to follow what my supervising teachers suggested. (Catherine)

These and the previous data highlight a demarcation between the two fields of interaction, the university and the school, evincing a university-school divide. We interpret this as the theory-practice gap defined by Pfeffer and Sutton (2000), wherein key players in associated institutions hold conflicting views about best practice. Student teachers and, by extension, some experienced teachers were unable to put into practice the preferred BLM theory because the pre-existing conditions of the fields of interaction were in conflict. We now extend this notion by focusing on reproduction of the theorypractice gap in practice.

Reproduction of the theory-practice gap in Teacher Education

A key feature of our analysis is that participants both as individuals and as part of a collective contributed to the reproduction of the gap between theory and practice. The data illustrate this insofar as ten of fourteen participants upheld the belief that, when compared with in-field experience, much of what goes on in teacher education courses is not relevant. The claim and indications of what is meant by relevance are contained in the following comments about first-year courses:

The Futures course was a load of rot. How will that kind of thing help me to teach? I really wonder why we did it. (Anita)

That course that was out there at the university for SOSE was totally ridiculous as far as I'm concerned. We had a couple of lessons and they took us... [on a camp]... to X (name withheld) and as far as I'm concerned I got nothing out of it. Definitely a general feeling, I would say. (Anthony) 
These informants' explanations of an absence of relevance can be explained through the pre-existing conditions of the individuals concerned. That is, anticipatory socialisation and prior attitudes and beliefs about the role of teacher education dictate that a restricted set of interactions should take place between participants and others in the environment (Chang, 2004). This did not include interactions such as excursions (SOSE) or studies of the implications of globalisation on the world at large (Futures). In their interactions with others, participants' judgments and perceptions were regulated by additional beliefs they had already formed about the nature and value of teacher education. Gay, for example, said she believed that "training can only take you to a certain point" and Inez noted that:

Uni is important for all the background stuff but I always knew I'd learn more from being in the classroom.

Similarly, our informants made clear distinctions between the educational functions of the university and the school in their development as professionals, as exemplified in Desley's comments:
Desley:
A lot of the theory was a bit out there. It would depend on the lecturer.
Interviewer:
Desley:
What is your concept of what theory means? Reading and writing. Theorists. The why you do things rather than how. What we did at uni. Learning it has been useful in some ways.
Interviewer: $\quad$ Did you believe it was useful when you were at uni?
Desley:
No, because you couldn't see it happening. It's different in schools. School tends to focus on content. Uni focuses on psychology of why rather than the content. There are different ways of teaching the lessons but, in the end, it's content.

These data associate theory with university and practice with schools. This is despite an acknowledgement by participants that the university program included both practical components and links with practice. For example, participants appreciated the practical application of what they learned in KLA courses and commented on the value of being taught by teachers who "came in" (Elizabeth) to the university environment as seconded and sessional staff. The program also entailed student teachers going out into the school environment through regular portal tasks and internship. Nevertheless, despite these acknowledged pre-existing conditions of the environment, what was strongly maintained was that the university was not about the "practice" of teaching that was perceived of instead as the jurisdiction of schools. Our informants reproduced and sustained the gap between the university and schools when they associated one environment with theory and the other with practice.

Taken together, in theoretical terms, the participants' data indicate that they could not be "talked out" of what they already believed (Knowles \& Holt-Reynolds, 1991, p. 103). 
Their pre-existing beliefs had generated a cultural expectation that there would be a theory-practice gap between the university and the school. They further acknowledged and accepted that cultural and institutional barriers between the two environments were not theirs to overcome. This interpretation is lent credence by participants' responses to the generalised other, namely, experienced teachers working in schools.

\section{Response to the generalised other}

The human response to the generalised other is not dependent on contextual proximity. The individual can define situations in the absence of other people (Shibutani, 1955), as exemplified in this study. During preparation, student teachers' beliefs and actions were continuously influenced and shaped by what they judged to inform the attitude of those in the school setting. That is, they reacted to their expectation of the generalised other (experienced teachers). We draw two examples from the data to provide evidence for this. In the university setting, Carl selected out from all the practices he was taught those he saw as having application in the school setting:

When it came to doing lesson planning, if I thought I could use it in the classroom then I sat up and took notice.

In interacting with one environment, the university, Carl made deliberate choices about the types of practices and activities that he believed would facilitate his orientation in another environment, the school. His decision-making was informed by his aspiration to adopt the attitudes of the generalised other in the school environment. He selected out from the university environment those things that he believed would help him gain membership in the school environment at some time in the future.

Our second example shows that expectations about the generalised other were powerful in the identity formation of some student teachers:

Some stuff [in the BLM] I couldn't see myself using as a teacher. Wasn't sure it would work. I talked to mum and my sister about things like the planning templates and they both said they'd never use them. Other things I was more interested in. (Bianca)

In eliciting the opinions of experienced teachers in her family, Bianca was searching for the attitudes of the group whose perspectives she wanted to assume. In doing so, she displayed a capability for vicarious role taking ("I couldn't see myself ..."), projecting herself into a future role defined by her expectation of what her membership of the group in the school environment would mean. In the case of both Carl and Bianca, the participants' $I$ determined what kind of environment was relevant to them as prospective teachers.

Bianca's remarks also illustrate the breadth of the representation of the generalised other, 'experienced teacher,' for this group of participants. Her mother and sister represent the collective. Consistent with Mead's view that the generalised other comprises a range of disparate attitudes, beliefs and behaviour, participants actively sought out and referred to perspectives of a number of others. Family member teachers featured especially in the 
discourse of several informants as well as Bianca, such as Earl whose wife had been teaching for five years:

I would sit at the dinner table and talk to my wife and say, look, this is happening. What can I do or how can I possibly get this across? Or this child just doesn't understand it. I explained it this way and this way and she would suggest, have you tried it this way? Have you done it another way?

Similarly, Anthony's perspectives were influenced by the practices of his son's teacher in a local elementary school:

I was so impressed with what [my son] was doing for this unit on Egypt that I rang his teacher and asked him how he did it, you know, the secret of his success.

These are instances of student teachers defining objects (e.g. teacher practice) and other people (family members) from the perspective that they seek to share with them. Informants visualised their proposed lines of action from this generalised standpoint (how to teach the unit on Egypt) and anticipated the reactions of others ("wasn't sure it would work"), thus regulating their professional behaviour (Shibutani, 1955).

At this point we suggest that the data show that pre-existing conditions across a range of individual characteristics and institutional arrangements, in the university and the school, have a defining effect on people in the liminal period between being a "student" and, later, a "teacher." The data reveal the dyadic nature of interactions between informants and others in the social group, reflecting what Mead refers to as rationality.

\section{Rationality}

Some interactions involved a coming together and taking up of ideas from both students and significant others in the school setting. Rationality is a multi-faceted and disequilibratory process, evident in this study in the imbalance between the levels of engagement of teachers with students' ideas than students with teachers'. According to respondents' comments, experienced teachers showed minimal interest in their ideas when they were students. However, once they were teachers some of their practices caught other teachers' attention, as illustrated by:

They were really keen to hear your opinion on some things you'd learned; they were really good at that. As with the Inspiration program that I talked about before, I'd had a little bit of dealing with that so I sat down with the Assistant Principal and said, well, this is what I've sort of learned. And the other teachers I work with, they were really keen to look at the program as well so we sat down and added this [program] to what we do. (Earl)

There was some stuff, like Google Earth, that the other [year level teachers] liked so I showed them how to use it. [They said they could] use it in a couple of the second term units. (Fiona) 
These are examples of rationalised social interaction (Mead, 1934) whereby participants (now teachers) both controlled their actions through the behaviour of others and controlled others' actions through their own. The behaviour of these individuals can be explained through the dynamic nature of their selves and the co-evolution of their $I$ through their mutual social interaction (Beames, 2005).

\section{Generalisations}

Our intention in this paper has been to demonstrate how Mead's theory of emergence predicts the obduracy of the theory-practice gap in front-end loading university programs. In using teacher education as an exemplar, we are not suggesting that all pre-professional programs are alike. On the contrary, we acknowledge that there are many differences between discipline areas in pre-service programs (Neville, Sherman, \& Cohen, 2005). What is more, those individuals entering pre-service teaching programs have been shown to carry with them preconditions unique to their discipline emerging from anticipatory socialisation into the profession (Lortie, 1975). Nevertheless, while acknowledging the use of a small study sample, we argue that an important theoretical insight emerges from this research that is in principle generalisable to other front-end loading programs.

The pre-existing conditions of front-end programs are often such that participants interact with different sets of conditions in the different fields of interaction of the university and the workplace, resulting in a power play between the two fields. While the discourse of many university programs holds that both fields contain similar and complementary frames of reference (see, for example, Beattie, 2001; Hudson, et al., 2001), participants tend to differentiate between the two fields and begin setting standards for themselves in ways that align with the workplace. The agentive power of students is significant in determining their trajectories through their undergraduate program. That is, they make active choices about what is important to them in terms of workplace practice and behaviour and about what they will adopt as their own. Given that individuals tend to adopt the behaviours and attitudes of the group to which they aspire (Mead, 1938), this generally means that they attach more importance to the practice of the workplace than the theory of their university learning. We propose that this is how the theory-practice gap in front-end loading programs and Teacher Education especially is co-produced and sustained. 
Allen, J. M., \& Butler-Mader, C. (2007). Experiences of practising teachers as lecturers in a pre-service teacher education program. Paper presented at the Central Queensland University Faculty of Arts, Humanities \& Education Research Group, Rockhampton, Qld.

Allen, J. M., \& Smith, R. A. (2007). Introduction. In P. Grainger \& J. M. Allen (Eds.), Dimensions of Learning in practice in Australian primary, secondary and tertiary education (pp. 19-27). Heatherton, Vic.: Hawker Brownlow Education.

Beames, S. (2005). Expeditions and the social construction of the self. Australian Journal of Outdoor Education, 9(1), 14-23.

Beattie, H. (2001). The theory practice interface: A case study of experienced nurses' perceptions of their role as clinical nurses. ACU, Ascot Vale, Vic.

Blumer, H. (1969). Symbolic interactionism: Perspective and method. Englewood Cliffs, NJ: Prentice Hall.

Boud, D. (2001). New practices for new times. In D. Boud \& N. Solomon (Eds.), Workbased learning: A new higher education? (pp. 3-17). Buckingham, UK: The Society for Research into Higher Education \& Open University Press.

Brouwer, N., \& Korthagen, F. A. J. (2005). Can Teacher Education Make a Difference? American Educational Research Journal, 42, 153-225.

Bullough, R. V., Jr., \& Draper, R. J. (2004). Making sense of a failed triad: Mentors, university supervisors, and positioning theory. Journal of Teacher Education, 55, 407-420.

Chang, J. H.-Y. (2000). Symbolic interaction and the transformation of class structure: The case of China. Symbolic Interaction, 23, 223-251.

Chang, J. H.-Y. (2004). Mead's theory of emergence as a framework for multilevel sociological inquiry. Symbolic Interaction, 27, 405-427.

Chang, J. H.-Y. (2005, Aug 12-15). Globalization and Ethnic Identification: A study of high school students in Taiwan. Paper presented at the American Sociological Association Conference, Philadelphia, PA.

Coffey, A., \& Atkinson, P. (1996). Making sense of qualitative data: Complementary research strategies. Thousand Oaks, CA: Sage.

Cohen, L., Manion, L., \& Morrison, K. (2007). Research methods in education (6th ed.). London: Routledge.

Cook, G. A. (1993). George Herbert Mead: The making of a social pragmatist. Urbana, IL: University of Illinois Press.

D'Andrade, R. (2006). Commentary on Searle's 'Social ontology': Some basic principles. Anthropological Theory, 6, 30-39.

Davison, E. J. (2005, Dec 12-15). The theory-practice gap: Where are we? Paper presented at the IEEE Conference, Seville, Spain.

El-Hani, C. N., \& Pihlström, S. (2002). Emergence theories and pragmatic realism. Essays in Philosophy, 3. Retrieved Septemberr 18, 2008, from http://www.humboldt.edu/ essays/pihlstrom.html

Hargreaves, D. H. (2000). The production, mediation and use of professional knowledge among teachers and doctors: A comparative analysis. In OECD (Ed.), Knowledge management in the learning society (pp. 219-236). Paris: OECD. 
Hudson, J. N., Buckley, P., \& McMillen, I. C. (2001). Linking cardiovascular theory to practice in an undergraduate medical curriculum. Advances in physiology education, 25, 193-201.

Kelchtermans, G., \& Vandenberghe, R. (1994). Teachers' professional development: A biographical perspective. Journal of Curriculum Studies, 26, 45-62.

Knowles, J. G., \& Holt-Reynolds, D. (1991). Shaping pedagogies through personal histories in preservice teacher education. The Teachers College Record, 93, 87113.

Korthagen, F. A. J., \& Kessels, J. P. A. M. (1999). Linking theory and practice: Changing the pedagogy of teacher education. Educational Researcher, 28(4), 4-17.

Landers, M. G. (2000). The theory-practice gap in nursing: The role of the nurse educator. Journal of Advanced Nursing, 32, 1550-1556.

Longmore, M. A. (1998). Symbolic interactionism and the study of sexuality. Journal of Sex Research, 35, 44-57

Lortie, D. C. (1975). Schoolteacher: A sociological study. Chicago: University of Chicago Press.

Lynch, D. E. (2003). So, you want to make a real difference? An introduction to learning management for the teacher in training. Unpublished Unpublished manuscript. CQU.

Lynch, D. E., \& Smith, R. A. (2006). Preparation of a learning manager in the BLM program. In R. Smith \& D. E. Lynch (Eds.), The rise of the learning manager: Changing teacher education (pp. 38-52). Frenchs Forest, NSW: Pearson Education.

Maines, D. R. (2001). The faultline of consciousness: A view of interactionism in sociology. New York: Aldine de Gruyter.

Mead, G. H. (1934). Mind, self, and society Chicago: University of Chicago Press.

Mead, G. H. (1938). The philosophy of the act. Chicago: University of Chicago Press.

Miles, M. B., \& Huberman, A. M. (1994). Qualitative Data analysis: An expanded sourcebook (2nd ed.). Thousand Oaks, CA: Sage.

Neville, K. S., Sherman, R. H., \& Cohen, C. E. (2005). Preparing and training professionals: Comparing education to six other fields. Washinton, DC: Finance Project.

Patrick, C.-j., Peach, D., \& Pocknee, C. (2008). The WIL [Work Integrated Learning] report: A national scoping study. [Australian Learning and Teaching Council (ALTC) Final Report]. Brisbane, Qld: Queensland University of Technology.

Perinbanayagam, R. S. (1986). The meaning of uncertainty and the uncertainty of meaning. Symbolic Interaction, 9, 105-126.

Pfeffer, J., \& Sutton, R. I. (2000). The knowing-doing gap: How smart companies turn knowledge into action. Boston, MA: Harvard Business School Press.

Reichers, A. E. (1987). An interactionist perspective on newcomer socialization rates. The Academy of Management Review, 12, 278-287.

Reid, A., \& O'Donoghue, M. (2001, September 24-26). Rethinking policy and practice in teacher education. Paper presented at the Australian Teacher Education Association Conference, Melbourne, Vic.

Reidy, J. M. (2006). Learning to work: Students' experiences during work placements. Melbourne, Vic: Melbourne University Press. 
Sarantakos, S. (2005). Social research (3rd ed.). Basingstoke, UK: Palgrave Macmillan. Shibutani, T. (1955). Reference groups as perspectives. American Journal of Sociology, 60, 562-569.

Shulman, L. S. (1992). Toward a pedagogy of cases. In J. H. Shulman (Ed.), Case methods in teacher education (pp. 1-30). New York: Teachers College Press.

Silverman, D. (Ed.). (2004). Qualitative research: Theory, method and practice (2nd ed.). London: Sage.

Smith, R. A., \& Moore, T. (2006). The learning management concept. In R. A. Smith \& D. E. Lynch (Eds.), The rise of the learning manager: Changing teacher education (pp. 9-23). Frenchs Forest, NSW: Pearson Education.

Spouse, J. (2001). Bridging theory and practice in the supervisory relationship: A sociocultural perspective. Journal of Advanced Nursing, 33, 512-522.

Vernon, G. M. (1965). Human interaction. New York: Ronald Press.

Yayli, D. (2008). Theory-practice dichotomy in inquiry: Meanings and preservice teacher-mentor teacher tension in Turkish literacy classrooms. Teaching and Teacher Education, 24, 889-900. 